\title{
A new combination in Peristethium (Loranthaceae) expands the genus' range into the Amazon-Cerrado ecotone
}

\author{
Claudenir Simôes CAIRES ${ }^{1 *}$, Kadja Milena GOMES-BEZERRA², Carolyn Elinore Barnes PROENÇA² \\ 1 Universidade Estadual do Sudoeste da Bahia, Departamento de Ciências Naturais. Vitória da Conquista, Bahia, Brazil. \\ 2 Universidade de Brasília, Instituto de Ciências Biológicas, Departamento de Botânica, Herbário UB. Brasília, DF, Brazil. biomilena@yahoo.com.br, cproenca@unb.br \\ * Corresponding Author: cscaires@hotmail.com
}

\section{ABSTRACT}

The genus Peristethium, characterized by determinate inflorescences protected by deciduous bracts, occurs in the northwest of South America, as well as Costa Rica and Panama. The main objective of this paper was to transfer one species to what we believe is its correct generic placement in Peristethium, that likewise implies in a shift of the genus' distribution beyond the Amazon. A new combination, Peristethium reticulatum, is proposed, based on Struthanthus reticulatus, described from Tocantins in 1980. The sexual dimorphism of the inflorescences of $P$. reticulatum (sessile male flowers and pedicellate female flowers) associated with male inflorescences that are inserted at leafless nodes are unique within the genus. The male flowers have dimorphic stamens, well-developed anthers and a pistiloid, whilst female flowers have robust styles and stigmas, and much reduced staminodes. Peristethium reticulatum and P. polystachyum occurs in the Amazon regions of Brazil, with the former recorded also in the ecotone with the Central Brazilian savannas (Cerrados).

KEYwORDS: Brazil, Floral dimorphism, Leaf architecture, Struthanthus.

\section{Uma nova combinação em Peristethium (Loranthaceae) expande sua distribuição até o ecótono Amazônia-Cerrado}

\section{RESUMO}

O gênero Peristethium, caracterizado por inflorescências determinadas protegidas por brácteas decíduas, ocorre no noroeste da América do Sul, além da Costa Rica e Panamá. O objetivo do presente trabalho foi transferir uma espécie para o que acredita-se ser seu correto posicionamento genérico em Peristethium, o que também implica em concomitante alteração da distribuição geográfica deste gênero para além da Amazônia. A nova combinação, Peristethium reticulatum, é proposta, baseada em Struthanthus reticulatus, descrita para o Tocantins em 1980. O acentuado dimorfismo sexual das inflorescências de $P$. reticulatum (flores masculinas sésseis e as femininas pediceladas), juntamente com a origem de inflorescências masculinas em nós áfilos são únicos dentro do gênero. As flores masculinas apresentam estames dimorfos, anteras desenvolvidas e pistilódio, enquanto as flores femininas possuem estiletes e estigmas robustos e estaminódio reduzido. Peristethium reticulatum e $P$. polystachyum ocorrem em regióes amazônicas do Brasil, sendo a primeira registrada também em ecótono com o Cerrado.

PALAVRAS-CHAVE: Arquitetura foliar, Brasil, Dimorfismo floral, Struthanthus. 
The genus Peristethium was proposed by Tieghem (1895) based on Loranthus leptostachyus Kunth, but the genus has been largely ignored until its re-establishment by Kuijt (2012), who proposed nine new combinations and described five new species. Amongst the 15 species currently recognized in the genus, only P. polystachyum (Ruiz \& Pav.) Kuijt occurs in Brazil (Kuijt 2012; Caires and Dettke 2013).

During our studies of the Brazilian Loranthaceae, we noted Struthanthus reticulatus, described by Rizzini (1980), that conspicuous, deciduous, chartaceous bracts, which put it within the modern circumscription of Peristethium (Kuijt 2012). Comparing its morphological characteristics with those of the species treated by Kuijt (2012) we conclude that it should be transfered to Peristethium. Peristethium reticulatum, comprehensively treated in this paper, thus becomes the second species of this genus to be recorded in Brazil.

The botanical collections of ten herbaria (BHCB, CEN, IAN, INPA, MG, NY, RB, S, SPF, UB; see Thiers 2012 for herbarium codes) were consulted. Those at NY were examined on-line.

Specimens were analyzed under a stereoscopic microscope, and the morphological terminology of Radford et al. (1974), Rua (1999) and Kuijt $(1981,2012)$ adopted. A distribution map was produced using ArcGIS 9.0; for specimens lacking geographic coordinates these were inferred.

Leaves were cleared according to Shobe and Lersten (1967), with modifications according to Caires et al. (2012). After clearing and staining, leaves were mounted between sheets of glass following Paiva et al. (2006) and GomesBezerra et al. (2011). Leaf architecture terminology followed Hickey (1974) and Ellis et al. (2009). To describe types of sclerenchyma cells, the terminology of Kuijt and Lye (2005) was followed.

Pollen grains analysis was done using a Scanning Electron Microscope (JSM-7001F, JEOL Ltda, Akishima, Tokyo, Japan) set to $15 \mathrm{KV}$ with a working distance of 7-10 mm. The pollen, obtained from inside the anthers, was fixed on stubs with carbon adhesive tape and metalized with gold in a metalizer (Bal-Tec SCD-050, Balzers, Schaan, Liechtenstein). Samples were described following the terminology of Barth (1965), Feuer and Kuijt (1985) and Koch et al. (2009).

Peristethium reticulatum (Rizzini) Caires, comb. nov. Struthanthus reticulatus Rizzini, Arq. Jard. Bot. Rio de Janeiro 24: 23. 1980. Type: Brazil, Northern Goiás [Tocantins], road to Miracema do Norte [Miracema do Tocantins], cerrado, parasite on G.T. Prance 58446 [Protium heptaphyllum (Aubl.) Marchand], 28/VII/1964, flowers green, G.T. Prance \& N.T. Silva 58445 (holotype RB; isotypes NY, UB!)

Shrub-like, robust hemiparasite, dioecious. Epicortical roots not seen. Young stems compressed (transverse section

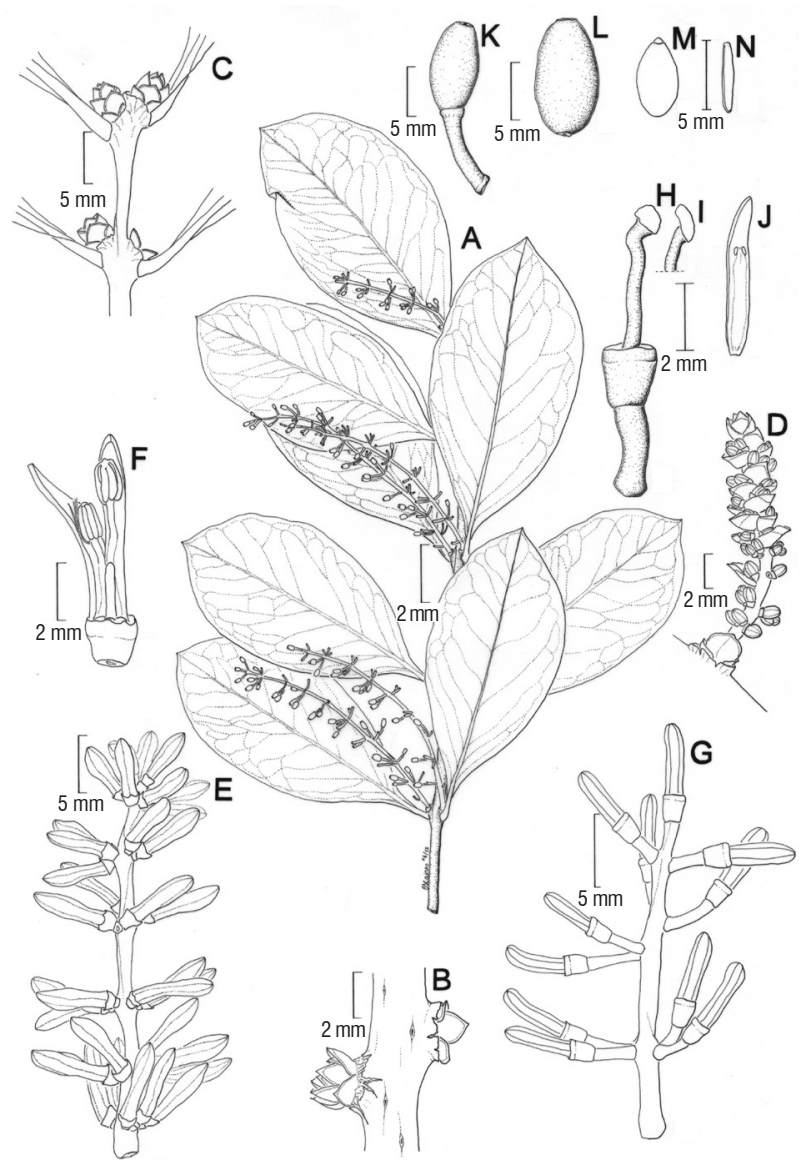

Figure 1- Peristethium reticulatum (Rizzini) Caires. A. Habit. B. Bracts subtending male inflorescences at leafless node. C. Bracts subtending axillary male inflorescences. D. Young male inflorescence with conspicuous bracts. E. Mature male inflorescence with bract scars. F. Male flower with pistiloid. G. Female inflorescence. H. Female flower. I. Variation in the shape of the stigma. J. Petal with staminode. K. Young fruit. L. Mature fruit. M. Endosperm. N. Embryo (A: Krukoff 1494; B-C, F: Grogan 252; D: Lobato 1975; E, L-N: Fróes 26626; G-J: Fróes 26620; K: Thomas 4340).

elliptic) to terete, glabrous; adult stems terete, glabrous, smooth, grayish, with elliptical lenticels; nodes swollen, with deep inflorescence scars; internodes 2-4.5 x 0.2-0.4 cm. Leaves opposite, decussate, rarely subalternate, coriaceous, shiny in sicco, obovate to elliptic, apex shortly acuminate, acuminate, acute or obtuse, sometimes somewhat retuse with an apiculum (Pereira-Silva \& Moreira 11312), base attenuate, margin smooth, entire, $5.5-11 \times 2.5-6 \mathrm{~cm}$; festoonate brochidodromous venation, the midvein sulcate on the upper surface and prominent on the lower surface, venation reticulate to the fourth order; secondary veins prominent and conspicuous; petiole 5-10 x 1.5-2 mm. Male inflorescences axillary, rarely arising laterally at leafless nodes, protected by deciduous bracts, $3 \times 0.2 \mathrm{~cm}$, these subtending 4-12 triads and a terminal flower; sometimes, a pair of diads and a pair 


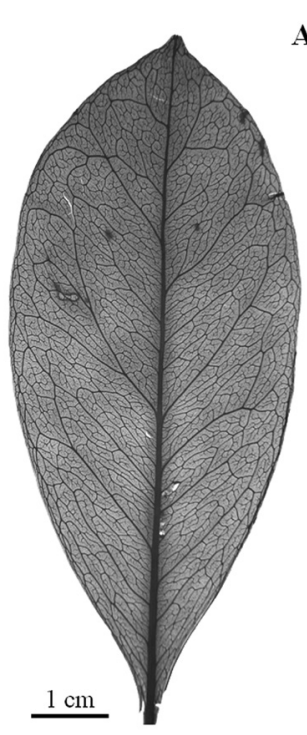

A

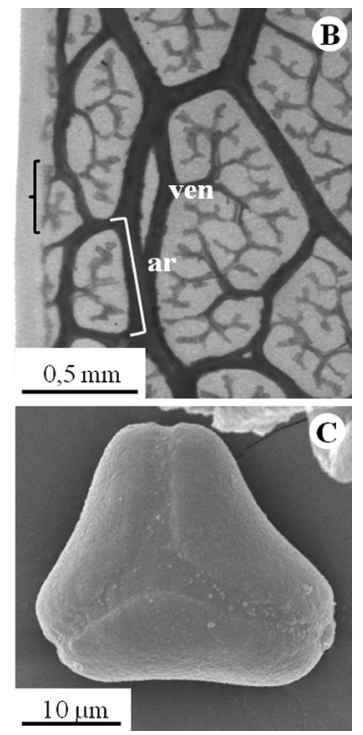

Figure 2- Peristethium reticulatum (Rizzini) Caires: Optical microscopy (A-B) and SEM (Scanning Electronic Microscopy) (C). A. Festoonate brochidodromous venation. B. Leaf margins with details of the areoles (ar), veinlets (ven), ultimate marginal vein (brace). C. Polar view of the pollen grain (A-B: Fróes 26626; C: Grogan 252).

of monads arising close to the apex, or just a pair of monads and a solitary terminal flower; bracts chestnut, with whitish margins, 2-3 x 1-2 mm. Male flowers with green floral buds, sessile, hexamerous, $6 \times 1 \mathrm{~mm}$, the base narrow and widening towards the apex; stamens dimorphic, filaments adnate to the petals, with fimbriate tufts at the base of the anther (Figure 1F); anther tetralocular, connective not prolonged; pistiloid present; pollen grains triangular, ca. $30 \mu \mathrm{m}$ diam., surface psilate and verrucose. Female inflorescences axillary, protected by dehiscent bracts, $3-11 \times 0.1-0.2 \mathrm{~cm}$, supporting 3-8 triads, 1-2 diads and 1-2 monads and a single terminal flower; sometimes lacking the triads; bracts chestnut to black with a whitish margin. Female flowers pedicellate, white or yellow, hexamerous, $5 \times 1 \mathrm{~mm}$, cylindric, thin, staminodes present or absent, stigma capitate; pedicel 2-10 x 0.5-1.5 mm. Fruits 7-9 × 3-4 mm, smooth, ovoid to ellipsoid, immature green, mature yellowish-orange, pale orange, red or black; endosperm greenish, ellipsoid, 5 x $2 \mathrm{~mm}$; embryo thin, $5 \mathrm{x}$ $1 \mathrm{~mm}$.

Additional specimens examined: Brazil. Amapá: Oiapoque, estrada que vai para o aeroporto, 13/X/1950, fl. female, R.L. Fróes 26620 (IAN, MG, UB); Ib., 13/X/1950, fl. male, R.L. Fróes 26626 (IAN, MG, UB). Maranháo: Estreito, Canteiro de obras próximo à pedreira, 6035'25”S, 47²7’21"W, 150 m, fr., 08/III/2007, G. Pereira-Silva \& G.A. Moreira 11312 (CEN). Mato Grosso: Santa Terezinha,

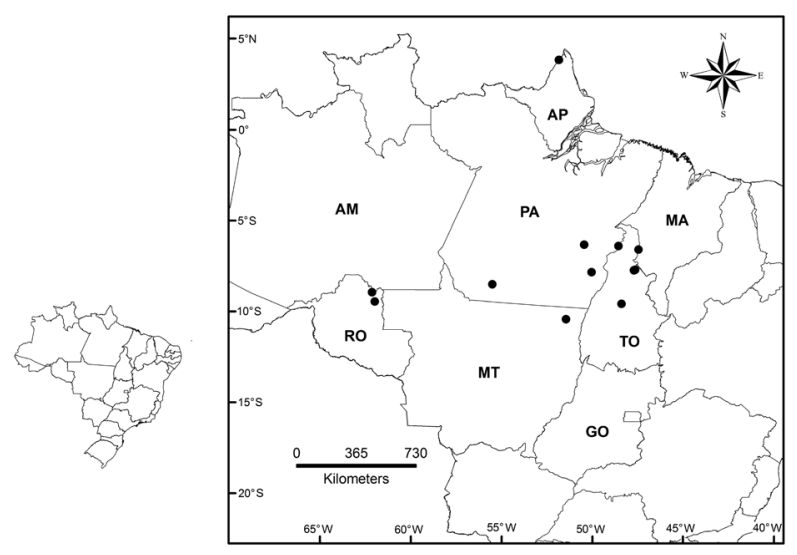

Figure 3.- Geographic distribution of Peristethium reticulatum (Rizzini) Caires in Amazonia and the Cerrado-Amazon ecotone (black circles). Brazilian states: $\mathrm{AM}=$ Amazonas, $\mathrm{AP}=$ Amapá, $\mathrm{GO}=$ Goiás, $\mathrm{MA}=$ Maranhão, $\mathrm{MT}=$ Mato Grosso, $\mathrm{PA}=$ Pará, $\mathrm{RO}=$ Rondônia and $\mathrm{TO}=$ Tocantins.

hills of Serra do Tapirapé, $21 \mathrm{~km} \mathrm{SW} \mathrm{of} \mathrm{Portal} \mathrm{do} \mathrm{Amazonia}$ (jct MT413 to Santa Terezinha \& BR158) along BR-158, $10^{\circ} 25^{\prime} \mathrm{S}, 51^{\circ} 27^{\prime} \mathrm{W}, 13 / \mathrm{X} / 1985$, fr., W.W. Thomas et al. 4340 (INPA, MG, SPF). Pará: Canaã dos Carajás, Floresta Nacional de Carajás - Serra Sul, 6¹9'14”S, 50²6’45”W, 725 m, 09/XII/2007, fr., N.F.O. Mota et al. 1137 (BHCB, MG, UB); [Novo Progresso]: BR 163, Cuiabá-Santarém Highway, km 884, northern foothills of Serra do Cachimbo, 11/XI/1977, fr., G. T. Prance et al. P25215 (MG); Pau D'arco, Marajoara, fl. male, J. Grogan 252 (IAN, INPA, MG); São Geraldo do Araguaia, Serra das Andorinhas, 03/XII/2001, fr., D.D. Amaral et al. 177 (MG). Rondônia: Machadinho [Machadinho D'Oeste], Distrito de Tabajara, estrada para 02 de novembro, 08/XI/1997, fl. male, L.C.B. Lobato et al. 1975 (MG); Ib., near Tabajara, upper Machado River region, XI-XII/1931, fr., B.A. Krukoff 1494 (S). Tocantins: Barra do Ouro, margem esquerda do córrego do Ouro, 7042'17'S, 47038'27”W, 140 m, 02/IX/2008, fl. female, G. PereiraSilva et al. 13701 (CEN); Ib., 7042'18”S, 47038'28”W, 140 m, 19/VIII/2010, fl. female, J.B. Pereira et al. 213 (CEN); Ib. Fazenda Santa Rosa, córrego Bacabal, 7043'56"S, 47042'16"W, 200 m, 04/IX/2008, fr., G. Pereira-Silva et al. 13722 (CEN); Ib., 7044'04”S, 47042'17”W, 200m, 19/ XI/2010, fr., J.B. Pereira \& J.P. Amaral 305 (CEN).

Peristethium reticulatum was found growing in terra firme forest, dry or seasonally inundated gallery forests, white sand fields (campinas de areia branca), shrubby canga vegetation and in Central Brazilian savannas (Cerrado) (Pereira-Silva et al. 13722). Recorded hosts are: Tapirira sp. (Anacardiaceae), Humiriaceae, and Norantea sp. (Marcgraviaceae) as well as Protium heptaphyllum (Aubl.) Marchand (Burseraceae) (Prance 
\&Silva 58446). Hyperparasitism was recorded for Mota 1137 (UB), which was parasitised by Cuscuta sp. (Convolvulaceae).

Peristethium reticulatum is easily recognized in the field as a robust plant, with conspicuously lenticelate branches (Figure 1B) and deep scars from the previous years' inflorescences.

In herbarium specimens, the leaves are very shiny, with an evident reticulum formed by the secondary and tertiary veins, a feature used by Rizzini (1980) to choose the species epithet.

Analysis of cleared leaves showed festoonate brochidromous venation, with veins to the fourth order (Figure 2A). Secondary veins form 8-12 conspicuous, prominent pairs, with a divergence angle of $45^{\circ}-70^{\circ}$; the intersecondary veins are exmedial and the tertiary veins are alternate-percurrent. The areoles are well developed, with 4-6 sides (Figure 2B), occurring at a density of c. $12 / \mathrm{mm}^{2}$; veinlets are dendritic (Figure 2B). The ultimate marginal veins incomplete (Figure 2B). No fibers, crystaliferous cells or sclereids were observed in the leaf mesophyll, only terminal tracheids were found, differing from those observed by Kuijt (2012) and Kuijt and Lye (2005) in other species of Peristethium.

Male inflorescences arise in the nodes of both new and old branches, usually in the leaf axils (Figure 1C), but spikes also arise from leafless nodes (see Fróes 26626, Grogan 252 and Lobato 1975; Figure 1B). All floral "units" (triads, diads or monads) are protected by deciduous bracts, present in young inflorescences (Figure 1D) but fully deciduous in mature inflorescences (Figure 1E). In general, inflorescences are formed by several pairs of sessile triads (the flowers are also sessile), up to the last nodes before the terminal flower, although 1-2 pairs of diads and sometimes 1-2 pairs of monads are present.

Pollen grains are triangular in polar view, oblate-spheroidal in equatorial view, c. $30 \mu \mathrm{m}$ in diameter, surface psilate to verrucose (Figure 2C), similar to those of Peristethium lojae (Kuijt) Kuijt (Kuijt 2012).

Female plants have only one inflorescence per leaf axil, which is usually larger than the inflorescences of male plants. Female flowers are all pedicellate and easily distinguishable from the male flowers by bud shape, the robust functional pistil and extreme reduction of the stamens (staminodes) (Figures $1 \mathrm{H}-\mathrm{J})$. Variability in inflorescence units is common, with some inflorescences composed of several pairs of triads, 1-2 pairs of monads and a terminal flower (Figure 1A) or a few pairs of diads, a single pair of monads and the terminal flower (Figure 1G).

Peristethium reticulatum is distinct from the other species of the genus by the complex inflorescences formed from different combinations of triads, diads and sessile monads, the sessile male flowers and the pedicellate female flowers. It is very similar to $P$. leptostachyum (Kunth) Tiegh., particularly in floral morphology, but leaf morphology and obviously pedicellate female flowers distinguish the two taxa.

\section{Key to the Brazilian species of Peristethium}

1. Female flowers pedicellate; male flowers with pistiloid; adult stems lenticellate ..... P. reticulatum

1'. Female flowers sessile; male flowers without pistiloid; adult stems smooth P. polystachyum

Peristethium reticulatum is reported from six Brazilian states, all within the Amazon region. Only specimens collected along the borders between the states of Tocantins (TO) and Maranháo (MA) can be considered to be in the transitional zone between the Amazon and the Cerrado biomes (Figure 3). Peristethium nitidum (Kuijt) Kuijt and $P$. roraimense (Steyerm.) Kuijt occur on the border between Venezuela, Guyana and near the northern borders of the state of Roraima (Brazil), while P. reticulatum occurs on the frontier between Amapá (Brazil) and French Guiana. These three species, and P. polystachyum, belong to a group of species that grow in the Amazon lowlands, as opposed to the remaining species of the genus that grow in the Andean regions of South America (Kuijt 2012).

\section{ACKNOWLEDGEMENTS}

We thank the Laboratório de Microscopia Eletrônica da Universidade de Brasília helpful staff, and herbarium curators for loans, images furnished (specially Dr. Marcelo F. Simon) and logistic support during our visits. CSC and KMG-B thank Coordenação de Aperfeiçoamento de Pessoal de Nível Superior (CAPES) for Ph. D. scholarships. This is publication 8 in the Parasitic Plants Research Group technical series.

\section{REFERENCES}

Barth, O.M. 1965. Glossário palinológico. Memórias do Instituto Oswaldo Cruz, 63: 133-162.

Caires, C.S.; Dettke, G.A. 2013. Loranthaceae in Lista de Espécies da Flora do Brasil. Jardim Botânico do Rio de Janeiro (http:// floradobrasil.jbrj.gov.br/jabot/floradobra sil/FB152). Accessed on $27 / 04 / 2013$.

Caires, C.S.; Gomes-Bezerra, K.M.; Proença, C.E.B. 2012. Novos sinônimos e uma nova combinação em Pusillanthus (Loranthaceae). Acta Botanica Brasilica, 26: 675-681.

Ellis, B.; Daly, D.C.; Hickey, L.J.; Johnson, K.R.; Mitchell, J.D.; Wilf, P.; Wing, S.L. 2009. Manual of leaf architecture. Cornell University Press, Ithaca.

Feuer, S.M.; Kuijt, J. 1985. Fine structure of mistletoe pollen VI. Small-flowered Neotropical Loranthaceae. Annals of the Missouri Botanical Garden, 72: 187-212.

Gomes-Bezerra, K.M.; Soares-Silva, L.H.; Gomes, S.M. 2011. Arquitetura foliar de las Lauraceae del Distrito Federal, Brasil, y nuevos patrones de venación propuestos. Gayana Botánica, 68: 1-15. 


\section{ACTA}

Hickey, L.J. 1974. Clasificación de la arquitectura de las hojas de dicotiledóneas. Boletin de la Sociedad Argentina de Botánica, 16: 1-26.

Koch, K.; Bhushan, B.; Barthlott, W. 2009. Multifunctional surface structures of plants: an inspiration for biomimetics. Progress in Material Science, 54: 137-178.

Kuijt, J. 1981. Inflorescence morphology of Loranthaceae - an evolutionary synthesis. Blumea, 27: 1-73.

Kuijt, J. 2012. Reinstatement and expansion of the genus Peristethium (Loranthaceae). Annals of the Missouri Botanical Garden, 98: 542-577.

Kuijt, J.; Lye, D. 2005. A preliminary survey of foliar sclerenchyma in Neotropical Loranthaceae. Blumea, 50: 323-355.

Paiva, J.G.A.; Carvalho, S.M.F; Magalhães, M.P.; Ribeiro, D.G. 2006. Verniz vitral incolor 500: uma alternativa de meio de montagem economicamente viável. Acta Botanica Brasilica, 20: 257-264.
Radford, A.E.; Dickison, S.C.; Massey, J.R.; Bell, C.R. 1974. Vascular Plant Systematics. Haper \& Row, New York.

Rizzini, C.T. 1980. Loranthaceae of the Central Brazil. Arquivos do Jardim Botânico do Rio de Janeiro, 24: 19-50.

Rua, G.H. 1999. Inflorescências - bases teóricas para su análises. Sociedad Argentina de Botánica, Buenos Aires.

Shobe, W.R.; Lersten, N.R. 1967. A technique for clearing and staining gymnosperm leaves. Botanical Gazette, 127: 150-152.

Thiers, B. 2012. Index Herbariorum: A global directory of public herbaria and associated staff. New York Botanical Garden's Virtual Herbarium. (http://sweetgum.nybg.org/ih). Access in 05/01/2013

Tieghem, P. van. 1895. Sur le groupement des espèces dans les Loranthées à calice dialysépale et anthères oscillantes out Struthanthées. Bulletin de la Société Botanique de France, 42: 161-180.

Recebido em 25/01/2013

Aceito em 19/06/2013 
